\title{
The effect of implemented pulsed electric field (PEF) treatment on the dehydrogenase activity of activated sludge
}

\author{
U. Koners ${ }^{1}$, W. Schmidt ${ }^{2}$, M. Löffler ${ }^{2}$, V. Heinz ${ }^{1}$ \& D. Knorr ${ }^{1}$ \\ ${ }^{I}$ Department of Food Biotechnology and Food Process Engineering, \\ Technical University of Berlin, Germany \\ ${ }^{2}$ Department of Supply and Disposal, Department of High Voltage \\ Technology, University of Applied Sciences Gelsenkirchen, Germany
}

\begin{abstract}
The implementation of sludge disintegration in wastewater treatment processes is a possible strategy of sludge minimisation. Many sludge disintegration technologies are being explored. A new additional method of disintegration is the application of pulsed electric fields (PEF). In the PEF technique short high voltage pulses are applied to generate an electric field in the sample, which builds up an electrical potential difference between the inner and outer side of the membrane. By exceeding a critical potential a perforation of the membrane is evoked (Zimmermann et al. [1]). A benefit of PEF application on subsequent aerobic and anaerobic treatment processes is shown (Koners et al. [2], Kopplow et al [3]).

In this research the attention is turned to the release of cell content and change in bio-activity of the sludge after PEF implementation. The most common tests to determine the disintegrative effect is the release of dissolved organic carbon (DOC) or the uptake of chemical oxygen demand (COD). As to determine additionally sludge activity a dehydrogenase assay (DHA) with the oxidoreduction dye resazurin was chosen. The DHA data are not dependent on the metabolism of a nutritive additive like glucose. DHA can be a useful monitoring parameter for sludge activity, though it correlates not always to found respiration activity (Strotmann et al. [4]). According to Ewald et al. [5] DHA with resazurin generally is a quick test for cell viability.

The disintegrative effect of PEF implementation was tested by DOC and DHA and compared to each other. The test leads to the conclusion that for each energy input the fraction of inactivated micro-organism keeps in the same range, unaffected of the dry substance content. Consequently PEF implementation is more energy efficient when the content of dry substances is high.

Keywords: disintegration, pulsed electric field, PEF, dehydrogenase assay, DHA, resazurin.
\end{abstract}




\section{Introduction}

Nowadays waste water treatment plants are facing high sludge disposal costs. Consequently sludge management becomes more important. Implementing sludge disintegration in the stage of wastewater treatment or in the sludge stage is a possible strategy of sludge minimisation. Now many sludge disintegration technologies are being explored and partially already being implemented, e.g. stirred ball-mill, ultrasonic disintegrator, ozone [6-11]. A new method of disintegration could be the application of pulsed electric fields (PEF). The special characteristic of the PEF implementation is the perforation of the cell membranes. The short pulses evoke an electric field in the liquid which builds up an electrical potential between the inner and outer side of the membrane. If the latter exceeds a critical potential of $1 \mathrm{~V}$, a perforation of the membrane is caused (Zimmermann et al. [1]). This perforation can be temporarily or permanent. For spherical cells an inversely proportional dependency between the cell size of perforated micro-organism and the field strength is assumed. If it is calculated according to Heinz et al. [12] a field strength E of at least $15 \mathrm{kV} / \mathrm{cm}$ is necessary for rotund micro-organism of a $0,44 \mu \mathrm{m}$ diameter. Due to the action of PEF the structure of the sludge is less influenced than by other disintegrative mechanical methods. Other methods are based on foremost effects on floc structure and ensuing cell rupture, e.g. ultrasonic (Lehne et al. [13]). So far the inactivation of micro-organism by PEF has been intensively investigated in the food-industry as an alternative non-thermal technology to the conventional thermal treatment (Heinz et al. [12]). In the field of sludge treatment only some researches have been realised $[2,3]$ by which a benefit of PEF application on subsequent aerobic and anaerobic treatment processes is shown.

As to explore the disintegrative effect of applied techniques the rate of chemical oxygen demand (COD) release as described in Müller et al [14] has become common. Alternatively the rate of dissolved organic carbon (DOC) release can be measured and similar results are achieved. The release tests base on the assumption that the release is compared to the total releasable organic compound by adding sodium hydroxide. The COD or DOC tests give a general overview and allow comparability to the results of other research teams. Nevertheless the sludge activity can not be deduced by these tests. The connection of the release of organic content and activity is important as it may help to distinguish where from the release is and to conclude which mechanism went on in the sludge by the applied technique. The following two examples demonstrate the importance. Firstly, there might be the case that the released COD is high, but the sludge activity keeps unaffected. This implies a release of only polymer substances which have been bound to flocs. Secondly, the combination of the test helps to control the energy efficiency for high energy inputs. If a huge amount or even all bacteria are already killed, any further additional energy input will lead to a break up of the material in the first sight. The turning point of emphasis between inactivation and break up can only be determined by the combination between DOC or COD and activity test. As time 
and applicability always play an important role, it was searched for a fast and easy practicable activity test.

The dehydrogenase assay (DHA) was found as a suitable test. In general several oxidoreduction dyes can be taken for the DHA, but resazurin is the only one which neither requires a step for extracting the oxidoreduction dye prior to photometry nor should be carried out in the absence of oxygen (Strotmann et al. [4]). These advantages explain why resazurin, which chemical synonym is Alamar Blue, was chosen. Chemically resazurin counts to the group of oxazines which contain six-membered heterocycles containing oxygen and nitrogen. In the DHA resazurin is implemented as an electron-acceptor dye. The blue resazurin gets irreversible converted to the pink resorufin. Subsequently a second reversible step from resorufin to the colourless dihydroresorufin can take place. The results can be binary evaluated in red/ blue by the shift of the extinction maximum from $610 \mathrm{~nm}$ to $580 \mathrm{~nm}$, or in fluorescent/ non-fluorescent. The nonfluorescent dye becomes highly fluorescent resorufin at $\mathrm{pH}$ values over 7,5.

Concerning microbial aspects resazurin replaces $\mathrm{O}_{2}$ as final $\mathrm{H}^{+} / \mathrm{e}^{-1}$ acceptor in the respiration chains of the micro-organisms of the sludge (Ryssov-Nielsen [16]). Until now it is not cleared in detail, where the conversion takes place. Zhang et al. [17], De Fries and Mitsuhashi [18] assume that it takes place by mitochondrial enzymes in eukaryotic cells. O'Brien et al. [19] could only approve at mammalian cells that it takes place in inner site. The implemented measurement of "general dehydrogenase activity" is distinguished from determinations of specific dehydrogenase activity (Ryssov-Nielsen [16]). The specific activities are measured, if the according specific enzyme substrate is applied, such as lactate or glucose. This explains why substrates cannot be utilised to increase the sensitivity of the test.

All over, DHA can be a useful monitoring parameter for sludge activity, though it is found not always correlating to respiration activity (Strotmann et al. [4]). According to Ewald et al [5] DHA with resazurin is generally a quick test as the reduction of resazurin starts within minutes and is completed after 60 minutes of incubation.

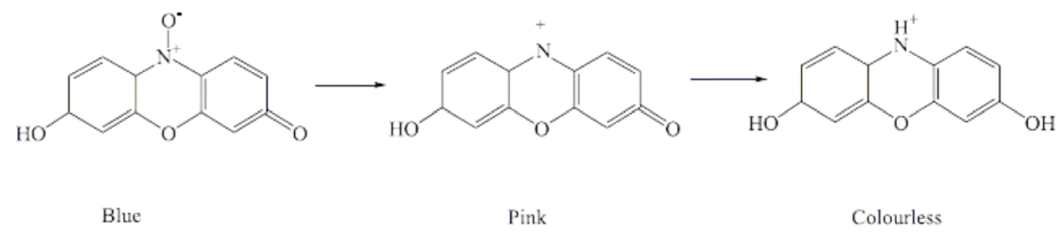

Figure 1: $\quad$ Resazurin, resorufin, dihydroresorufin (Guerin et al. [15]).

\section{Methods}

\subsection{PEF treatment}

The pulses were applied with a high electric field apparatus working with voltages up to $20 \mathrm{kV}$. The PEF facility as shown in Figure 2 was modified by 
using capacities from $20 \mathrm{nF}$ up to $50 \mathrm{nF}$ between the resistor R1 of $100 \mathrm{k} \Omega$ and the spark gap. The discharge voltage of $\mathrm{Cl}$ and the field strength across the treatment chamber were adapted by the spark gap. A co-linear treatment chamber with an electric field parallel to the sludge flow was used. The electric energy input in eqn. (1)

$$
E_{e}=n \cdot \frac{1}{2} \cdot C_{1} \cdot U_{0}^{2}
$$

was estimated by number of pulses $n$, the capacity $C 1$ and charging voltage $U_{0}$ at the generator. The parameters of PEF-treatment are a field strength of $E=7$ to $19 \mathrm{kV} / \mathrm{cm}$, a frequency of 20 to $80 \mathrm{~Hz}$, a resistance of about $1 \mathrm{k} \Omega$ in the treatment chamber and an energy input of $\mathrm{E}_{\text {spec }}=70-250 \mathrm{~kJ} / \mathrm{kg}$ liquid activated sludge. The electric energy input was experimentally confirmed by measuring to ohmic heating, thus thermal energy

$$
E_{0}=m \cdot c \cdot \Delta T
$$

by the help of the temperature difference $\Delta \mathrm{T}$ of the sludge. The heat capacity of water $\mathrm{c}=4,187 \mathrm{~kJ} /(\mathrm{kg} \cdot \mathrm{K})$ was assumed for the sludge, though it is lowered by the suspended solids (SS).

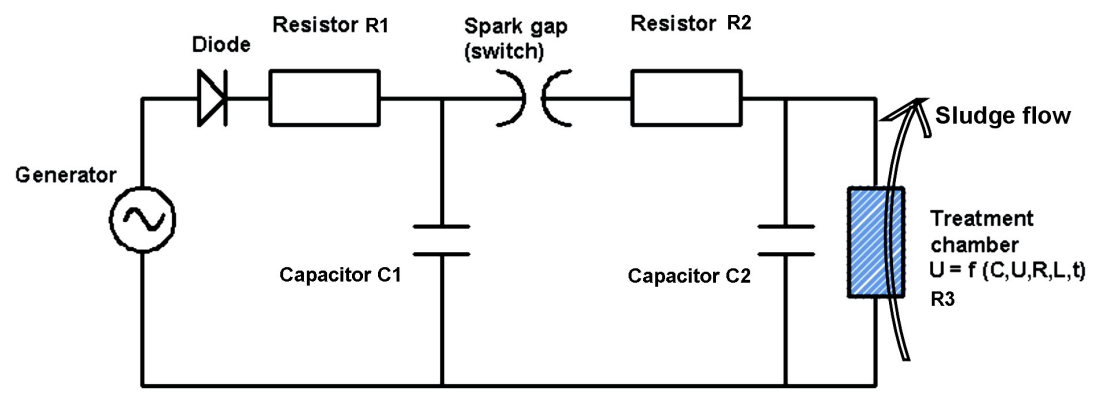

Figure 2: Schematic diagram of PEF facility.

\subsection{Analysis}

Before measuring DOC, the supernatant was filtrated at a pore size of $0,45 \mu \mathrm{m}$. The DOC values according to DIN EN [20] were measured with Shimadzu TOC-5000 Total Organic Carbon Analyzer by catalytic oxidation at $680^{\circ} \mathrm{C}$. DOC has been calculated by the difference between total carbon (TC) and inorganic carbon (IC).

For the degree of cell disruption the biochemical parameter COD is suitable parameter (Müller et al. [14]). The maximum releasable organic compounds $(\mathrm{COD} a)$ can be released by adding 1-molar sodium hydroxide (Müller et al. [21]). The degree of release can be evaluated using the $\mathrm{COD}_{u}$ of the untreated and the $\mathrm{COD}_{\mathrm{m}}$ of the treated sludge. In this research they have been substituted by the DOC values according to eqn. (3) as follows:

$$
D D_{D O C}=\left[\left(D O C_{m}-D O C_{u}\right) /\left(D O C_{a}-D O C_{u}\right)\right] \cdot 100 \%
$$


The suspended solids (SS) and volatile suspended solids (VSS) have been determined according to DIN [22]. Samples were taken from the wastewater treatment plant Gelsenkirchen-Picksmühlenbach from the Emscher Genossenschaft, Germany and Stahnsdorf from the Berliner Wasserbetriebe, Germany.

\subsection{Dehydrogenase assay (DHA)}

The test by EWALD et al. [5] was adopted in a slightly modified form. A resazurin-solution was prepared by filling up $60 \mathrm{mg}$ of resazurin, 3,4 g imidazole with $1000 \mathrm{ml}$ distilled water and adjusting of the $\mathrm{pH}$-value to $\mathrm{pH} 6,3$ by hydrochloric acid. The resazurin-solution has to be kept in the dark at $4{ }^{\circ} \mathrm{C}$ and regularly proven by a blind test, if its extinction did not reduce. The boratebuffer-solution contains 3,81g sodium-tetra-borate per $100 \mathrm{ml}$ distilled water. The solution is fixed to at least $\mathrm{pH} 11$ by sodium-hydroxide. For the test itself $1 \mathrm{ml}$ of resazurin-solution and $5.5 \mathrm{ml}$ tap water are filled in a test tube and tempered at $37^{\circ} \mathrm{C}$ for $10 \mathrm{~min} .0,5 \mathrm{ml}$ of sludge with a dry substance content of not more than $4 \mathrm{~g} / \mathrm{l}$ are added and the mixed tube being incubated for $60 \mathrm{~min}$. During incubation the test tubes are agitated every $10 \mathrm{~min}$. At the end of incubation the reaction is stopped by adding $1 \mathrm{ml}$ borate-buffer. Of each sample 3 tests and one blank value, in which the borate-buffer has been added before incubation, have been applied. After $5 \mathrm{~min}$ centrifugation at $3000 \mathrm{rpm}$ the samples are measured at $602 \mathrm{~nm}$ in reference to distilled water. The wavelength is chosen according to the maximum extinction of the blank sample measured by the photometer. For best results the extinction of the blank should be around 1 .

The data are evaluated according to eqn. (4):

$$
A_{S}=\frac{E_{B}-E_{P}}{S S} \cdot F_{1} \cdot F_{2}
$$

The $A_{S}$ describes the specific dehydrogenase activity ( $\mu$ g reduced resazurin $/ \mathrm{mg}$ $\mathrm{SS}) . \mathrm{E}_{\mathrm{B}}$ is the measured extinction of the blank value, $\mathrm{E}_{\mathrm{P}}$ the mean of measured extinction of the samples, $F_{1}$ the calibration factor of the resazurin concentration, which amounts 100 for an extinction of 1 , and $F_{2}$ the dilution factor of sludge. The inhibition of the sludge activity by PEF application is calculated by

$$
\text { Inhibition }=\left[1-\left(\frac{A_{\text {Ssample }}}{A_{\text {Scontrol }}}\right)\right] \cdot 100 \% \text {. }
$$

\section{Results and discussion}

Firstly, it was tested, if all resazurin was transformed to resorufin. The treated samples were measured at $601 \mathrm{~nm}$ and $571 \mathrm{~nm}$. The results of one sample series are shown in Figure 1. The results show a good correlation between resazurin and resorufin. If low degrees of inactivation are reached, lower inactivation rates at $571 \mathrm{~nm}$ than at $602 \mathrm{~nm}$ were found, which was probably evoked by the explained cycle from resorufin to the colourless dihydroresorufin. 
Further on the test performance of the DHA assay was tested on anaerobically digested sludge and aerobically activated sludge. The reduction of the blank without added sample lowered in comparison to the blank with sample lowered about 68 to $75 \%$ for anaerobic sludge and 10 to $20 \%$ for activated sludge. According to O'Brien et al. [19] the reduction of resazurin can take place chemically by the media or by enzymes. The huge initial reduction by the anaerobic sludge can be explained by the low redox-potential of about $-300 \mathrm{mV}$ to $-450 \mathrm{mV}$, which evokes a chemical degradation, while the biological activity was stopped by the borate-buffer. The reduction of extinction in case of the biological activated sludge was assumed as tolerable, as still enough resazurin was left in the solution for biological degradation. Because of this test performance only activated sludge was tested on its reduction of DHA after PEF application.

The effect of PEF implementation on the activity of aerobic sludge with different SS contents was tested. Figure 3 shows that the SS content plays a minor role to the inactivation rate. The rate keeps stable for each PEF set-up. So it can be concluded that the energy efficiency of PEF disintegration can be increased by raising the SS content. Similar results were taken from the release of the organic content $\left(\mathrm{DD}_{\mathrm{TOC}}\right)$ in a test series with an other activated sludge origin and a field strength of $17 \mathrm{kV} / \mathrm{cm}$. Figure 4 shows that the degree of organic release per specific energy input varies in the range of 0,08 and $0,14 \% /(\mathrm{kJ} / \mathrm{kg})$ though the samples were taken at different days and with different $\mathrm{E}_{\text {spec. }}$. This confirms the practical advice, that the sludge should be disintegrated at high SS contents in order to apply the PEF more energy efficient. Despite a constant energy input less micro-organism are inactivated at $7 \mathrm{kV} / \mathrm{cm}$ than at $14 \mathrm{kV} / \mathrm{cm}$, as shown in Figure 3. This results from the mechanism that the size of effected micro-organism is dependent on the field strength. Under the presetting of spherical organism micro-organism are affected larger than 9,5 $\mu \mathrm{m}$ diameter and $4,8 \mu \mathrm{m}$ diameter, respectively.

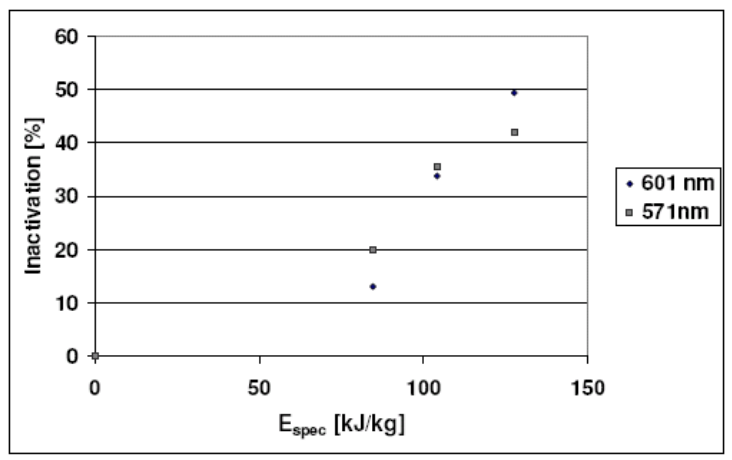

Figure 3: Measured inactivation after PEF implementation at $17 \mathrm{kV} / \mathrm{cm}$ at a wavelength of $571 \mathrm{~nm}$ and $601 \mathrm{~nm}$, SS content of $10,8 \mathrm{~g} / \mathrm{kg}$. 


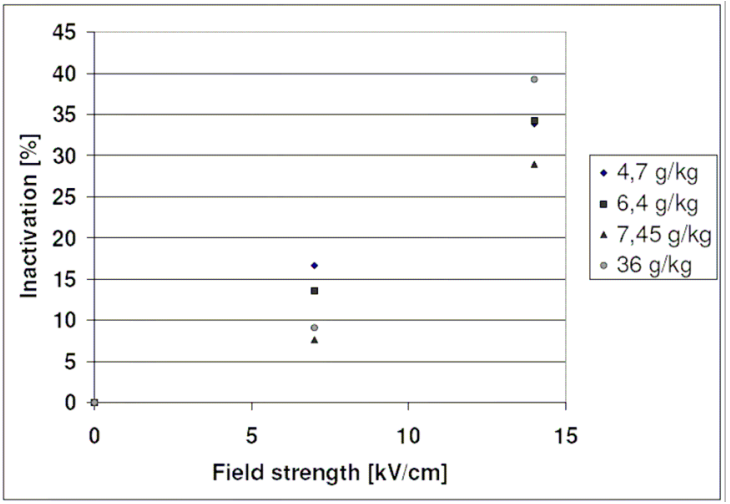

Figure 4: Inactivation rates by $\mathrm{E}_{\mathrm{spec}}=88 \mathrm{~kJ} / \mathrm{kg}$ of an activated sludge at different SS contents.

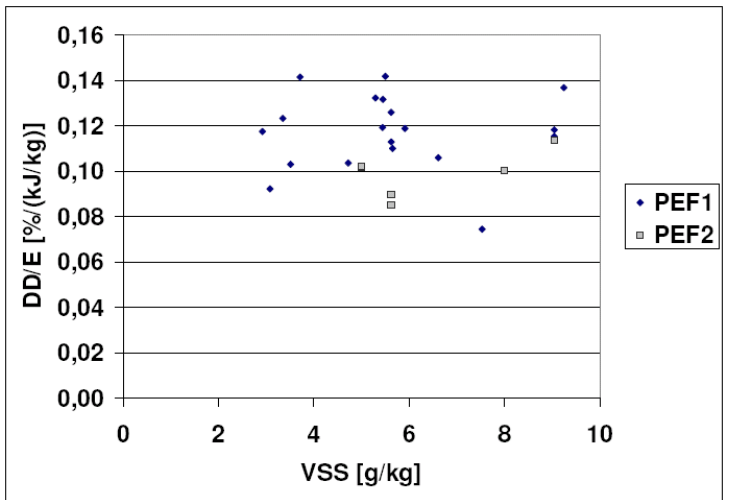

Figure 5: Released of total organic content per energy input $\left(\mathrm{DD}_{\mathrm{TOC}} / \mathrm{E}_{\mathrm{spec}}\right)$ for different VSS contents.

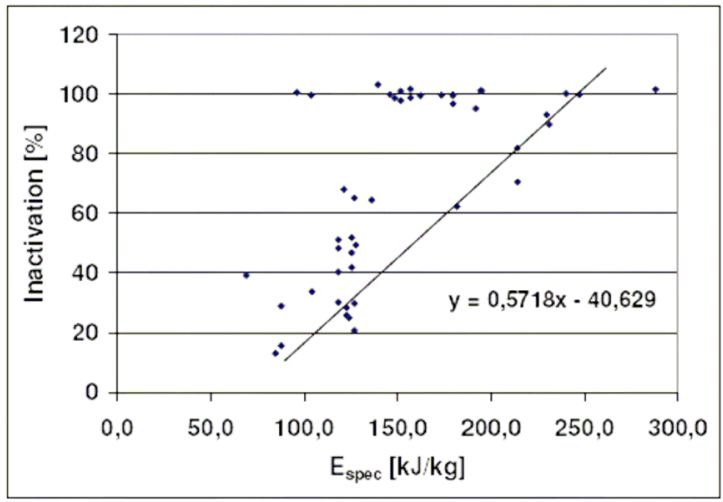

Figure 6: Inactivation rate vs. energy input $\mathrm{E}_{\mathrm{spec}}$. Samples were treated with field strengths from $15 \mathrm{kV} / \mathrm{cm}$ up to $19 \mathrm{kV} / \mathrm{cm}$. 
As the influence of the SS content is minor, the results of samples of two different WWTP containing different amounts SS are shown in Figure 6. These samples were treated at field strengths from 15 to $19 \mathrm{kV} / \mathrm{cm}$. The inactivation is presented versus different energy inputs. Under the given conditions no direct correlation can be detected between inactivation and energy input. This may be deduced to different initial sludge characteristics and stress situations by sample drawing and transport. However, the at least achievable minimal inactivation can be derived from Figure 6 . For $100 \mathrm{~kJ} / \mathrm{kg}$ liquid it amounts $16,5 \%$ though it is also possible to achieve $100 \%$ of inactivation for the same energy input. Implementing an energy input of $246 \mathrm{~kJ} / \mathrm{kg}$, it can be assumed that $100 \%$ have been inactivated. For these tests the treatment was not combined to thermal treatment. As it is shown by Heinz et al. [25] a higher initial temperature has a synergetic effect on the inactivation by PEF treatment, it can be advised to use the combination in order to lower the threshold energy input for a guaranteed $100 \%$ inactivation of the micro-organism. If an inactivation higher than $100 \%$ is achieved, the borate buffer of the blank sample did not inactivate all microorganism and it might be necessary to use the buffer with a $\mathrm{pH}$ value higher than pH 11.

\section{Conclusions}

The application of the DHA assay has been tested for the PEF application as a cheap and practicable test for monitoring the activity of the activated sludge. For the anaerobically digested sludge the test is not recommendable.

The DHA assay and the degree of released organic content showed, that the inactivation and organic content release by PEF application are not affected the amount of SS content. A minimal inactivation of the dehydrogenase activity can be calculated for each energy input. Considerably higher inactivation can also be achieved for the calculated energy input. A $100 \%$ inactivation of the dehydrogenase activity was achieved by an energy input from $100 \mathrm{~kJ} / \mathrm{kg}$ to $250 \mathrm{~kJ} / \mathrm{kg}$ liquid. For separate sludge samples and test series the results of the DHA fit very well, but for a general application for sludges of different origins and characteristics it has to be applied carefully and the results can only be generalised with some caution.

\section{Acknowledgement}

Thanks go to the Lippe-Emscher-Genossenschaft, Germany, and the Berliner Wasserbetriebe, Germany, for support by providing us with the sludge samples.

\section{References}

[1] Zimmermann, U.; Pilwat, G. \& Riemann, F., Dielectric breakdown in cell membranes. Biophysical Journal, 14, pp. 881-899, 1974. 
[2] Koners, U., Toepfl, S., Heinz, V., Camacho, P., Ginestet, P. \& Knorr, D., Application of Pulsed Electric Field Treatment for sludge reduction on waste water treatment plants. Proc. of the $2^{\text {nd }}$ European Pulsed Power Symposium EPPS 2004. Ed.: International Society on Pulsed Power Applications, Shaker: Aachen, pp. 47-52, 2004.

[3] Kopplow, O., Barjenbruch, M. \& Heinz, V., Sludge pre-treatment with pulsed electric fields. Water Science and Technology, 49(10), pp. 123129, 2004.

[4] Strotmann, U. J., Butz, B. \& Bias, W.-R., The dehydrogenase assay with resazurin: Practical performance as a monitoring system and $\mathrm{pH}$ dependent toxicity of phenolic compounds. Ecotoxicology and Environmental Safety, 25, pp. 79-89, 1993

[5] Ewald, E., Herrmann, K. \& Weismann, M., Kurzzeittest für die Bestimmung der Dehydrogenasenaktivität von Belebtschlämmen. Vom Wasser, 68, pp. 165-176, 1987.

[6] Böcker K., E., B., Kopp, J., Kopplow, O., Müller, J., Neis, U., Oles, J., Schmelz, K.-G., Seiler, K., Thiem, A., Wendler, D. \& Winter, A., Wirtschaftlicher und betrieblicher Vergleich verschiedener Verfahren zur Klärschlammdesintegration. KA Abwasser Abfall, 52(2), pp. 189-196, 2005

[7] Camacho, P., Deleris, S., Geaugey, V., Ginestet, P. \& Paul, E., A comparative study between mechanical, thermal and oxidative disintegration techniques of waste activated sludge. Water Science and Technology, 46(10), pp. 79-87, 2002.

[8] Diehm, B., Setzer, T. \& Kapp, H., Desintegration von Rücklaufschlamm zur Verbesserung der Denitrifikation. KA Abwasser Abfall, 51, pp. 396-403, 2004.

[9] Müller, J. A., Winter, A. \& Strünkmann, G., Investigation and assessment of sludge pre-treatment processes. Water Science and Technology, 49(10), pp. 97-104, 2004

[10] Odegaard, H., Sludge minimization technologies - an overview. Water Science and Technology, 49(10), pp. 31-40, 2004.

[11] Schmelz, K.-G. \& Müller, J., Klärschlammdesintegration zur Verbesserung der Faulung - Ergebnisse großtechnischer Parallelversuche. KA Abwasser Abfall, 51, pp. 632-642, 2004.

[12] Heinz, V., Alvarez, I., Angersbach, A. \& Knorr, D., Preservation of liquid foods by high intensity pulsed electric fields - basic concepts for process design. Trends in Food Science \& Technology, 12, pp. 103-111, 2002

[13] Lehne G., Müller, J. \& Schwedes J., Mechanical disintegration of sewage sludge. Water Science and Technology, 43(1), pp. 19-26, 2000.

[14] Müller, J., Lehne, G., Schwedes, J., Battenberg, S., Näveke, R., Kopp, J., Dichtl, N., Scheminski, A., Krull, R. \& Hempel, D.C, Disintegration of sewage sludge and influence on anaerobic digestion. Water Science Technology, 38(8-9), pp. 425-433, 1998. 
[15] Guerin, T. F., Mondido, M., McClenn, B. \& Peasley, B., Application of resazurin for estimating abundance of contaminant-degrading microorganism. Letters in Applied Microbiology, 32, pp. 340-345, 2001.

[16] Ryssov-Nielsen, H., Measurement of the inhibition of respiration in activated sludge by a modified determination of the TTC-dehydrogenase acticity. Water Research, 9, pp. 1179-1185, 1975.

[17] Zhang, H.-X., Du, G.-H. \& Zhang, J.-T., Assay of mitochondrial functions by resazurin in vitro. Acta Pharmacol. Sin., 25(3), pp. 385-389, 2004.

[18] De Fries, R. \& Mitsuhashi, M., Quantification of mitogen induced human lymphocyte proliferation: Comparison of the Almar blue assay to ${ }^{3} \mathrm{H}$-thymidine incorporation assay. J. Clin. Lab. Anal., 9, pp. 89-95, 1995.

[19] O'Brien, J., Wilson, I., Orton, T. \& Pognan, F, Investigation of the Almar Blue (resazurin) fluorescent dye for the assessment of mammalian cell cytotoxicity. European Journal of Biochemistry, 267, pp. 5421-5426, 2000.

[20] DIN EN 1484, Anleitungen zur Bestimmung des gesamten organischen Kohlenstoffs (TOC) und des gelösten organischen Kohlenstoffs (DOC). 1997.

[21] Müller, J., Thiem, A., Eder, B., Günthert, F.W., Hruschka, H., Kopp, J., Kunz, P.M., Otte-Witte, R., Schmelz, K.-G. \& Seiler, K., Verfahren und Anwendungsgebiete der mechanischen Klärschlammdesintegration. $K A$ Abwasser Abfall, 47(4), pp. 570-576, 2000.

[22] DIN 38409-1, Summarische Wirkungs- und Stoffkenngrößen (Gruppe H); Bestimmung des Gesamttrockenrückstandes, des Filtratrockenrückstandes und des Glührückstandes (H1), 1987.

[23] Perrot, S., Dutertre-Catella, H., Martin, C., Rat, P. \& Warnet, J.-M., Resazurin metabolism assay is a new sensitive alternative test in isolated pig cornea. Toxicological sciences, 72, pp. 122-129, 2003.

[24] Angersbach A., Heinz, V. \& Knorr, D., Effects of pulsed electric fields on cell membranes in real food systems. Innovative Food Science and Emerging Technologies, 1, pp. 135-149, 2000.

[25] Heinz, V., Toepfl, S. \& Knorr, D., Impact of temperature on lethality and energy efficiency of apple juice pasteurization by pulsed electric field treatment. Innovative Food Science and Emerging Technologies, 4(2), pp. 167-175, 2002. 